Article

\title{
Bisphenol-A and Nonylphenol Induce Apoptosis in Reproductive Tract Cancer Cell Lines by the Activation of ADAM17
}

\author{
Paulina Urriola-Muñoz ${ }^{1,2,+}$ (i) , Raúl Lagos-Cabré ${ }^{2,+}{ }^{\text {, Daniel Patiño-García }}{ }^{2}{ }^{\mathbb{D}}$, Juan G. Reyes ${ }^{1}$ \\ and Ricardo D. Moreno ${ }^{2, * \text { (iD }}$ \\ 1 Instituto de Química, Pontificia Universidad Católica de Valparaíso, Valparaíso 2340000, Chile; \\ paulina.urriola@gmail.com (P.U.-M.); juan.reyes@pucv.cl (J.G.R.) \\ 2 Departamento de Ciencias Fisiológicas, Facultad de Ciencias Biológicas, Pontificia Universidad Católica de \\ Chile, Alameda 340, Santiago 7820436, Chile; rclagos@uc.cl (R.L.-C.); dafpaga@gmail.com (D.P.-G.) \\ * Correspondence: rmoreno@bio.puc.cl; Fax: +56-2-222-5515 \\ + These authors contribute equally to this work.
}

Received: 19 June 2018; Accepted: 26 July 2018; Published: 31 July 2018

\begin{abstract}
Endocrine-disruptor chemicals (EDCs), such as bisphenol A (BPA) and nonylphenol (NP), have been widely studied due to their negative effects on human and wildlife reproduction. Exposure to BPA or NP is related to cell death, hormonal deregulation, and cancer onset. Our previous studies showed that both compounds induce A Disintegrin And Metalloprotease 17 (ADAM17) activation. Here, we show that BPA and NP induce apoptosis in prostate and ovary cancer cell lines, in a process dependent on ADAM17 activation. ADAM17 knockdown completely prevented apoptosis as well as the shedding of ADAM17 substrates. Both compounds were found to induce an increase in intracellular calcium $\left(\mathrm{Ca}^{2+}\right)$ only in $\mathrm{Ca}^{2+}$-containing medium, with the NP-treated cells response being more robust than those treated with BPA. Additionally, using a phosphorylated protein microarray, we found that both compounds stimulate common intracellular pathways related to cell growth, differentiation, survival, and apoptosis. These results suggest that BPA and NP could induce apoptosis through ADAM17 by activating different intracellular signaling pathways that may converge in different cellular responses, one of which is apoptosis. These results confirm the capacity of these compounds to induce cell apoptosis in cancer cell lines and uncover ADAM17 as a key regulator of this process in response to EDCs.
\end{abstract}

Keywords: apoptosis; endocrine-disruptor chemicals; ADAM17; cancer cell lines

\section{Introduction}

Endocrine-disruptor chemicals (EDCs) is the given name of a wide variety of compounds that disrupt the internal hormonal balance in humans and wildlife animals, leading to transient and/or permanent negative effects [1-5]. Bisphenol A (BPA) and nonylphenol (NP) are two of the most known EDCs used in the plastic and detergent industry [2,6], and these can be found in human biological samples (serum, breast milk, urine, fetal blood, and umbilical cord blood) [2,7]. NP is a degradation product of alkylphenol ethoxylates, which are used in the plastic industry for manufacturing dentistry, food packaging, textiles, pesticides, detergents, paints, and cosmetics [2,7]. On the other hand, the monomer BPA is one of the principal components of polycarbonate plastics and epoxy resins used worldwide [2,7]. BPA contamination occurs due to its leeching from plastics and resins used in the alimentary industry, and eventually reaching food and liquids consumed by humans and animals [2,8].

Several studies in animal models have shown adverse effects of BPA and NP in the male reproductive tract, such as reduced testis size, hormonal deregulation, germ cell apoptosis, 
and decrease in spermatozoa production [1,3,4,9-12]. Interestingly, EDCs have also been related to a predisposition to several types of cancer $[2,5,13-16]$. In this context, it has been shown that low levels of BPA increase the risk of hormone-dependent cancer in human prostate stem-like cells by measuring carcinogenesis markers in BPA-treated samples [5]. Similar effects were observed in mice, where BPA exposure during neonatal period increased prostatic intraepithelial neoplasia incidence in adulthood [17]. Low levels of BPA and NP have also been related to increased migration of BG-1, SKOV3, and A2780 ovarian cancer cells [18-20]. Interestingly, BPA treatment upregulates matrix metalloproteases and apoptosis-related genes in the ovarian cancer cell line SKOV3 [20]. This information only adds to the wide range of negative effects of these compounds.

Previously, we have shown that BPA and NP induce the release of Tumor Necrosis Factor $\alpha$ (TNF), Transforming Growth Factor $\alpha$ (TGF $\alpha$ ), and Heparin-binding EGF-like Growth Factor (HB-EGF) from plasma membrane by A Disintegrin And Metalloprotease 17 (DAM17) [21-23], and that BPA and NP induce apoptosis in male germ cells by activating p38 MAPK and ADAM17 [23-25]. ADAM17 is a transmembrane metalloprotease involved in the release of several substrates from the cell surface to the extracellular medium, activating or inhibiting signaling pathways involved in a myriad of cellular and physiological processes [26,27]. Interestingly, a pharmacological blocker of ADAM17 is able to prevent the BPA- and NP-induced apoptosis of germ cells, suggesting it as a putative molecular target [23]. In addition, other studies have shown that in vitro NP induces the apoptosis of neurons and thymocytes $[28,29]$ in a mechanism that depends on the increased intracellular calcium $\left(\mathrm{Ca}^{2+}\right)$ concentration $\left(\left[\mathrm{Ca}^{2+}\right]_{\mathrm{i}}\right)$ induced by NP [30]. Interestingly, both compounds have been shown to modulate in vitro intracellular $\mathrm{Ca}^{2+}$ levels in different cell types [31-35], suggesting that it is possible to hypothesize a mechanistic relationship between perturbed $\mathrm{Ca}^{2+}$ levels, ADAM17 activation, and cell apoptosis.

In this work we show that BPA and NP differentially induce apoptosis in cancer cell lines in a mechanism dependent upon ADAM17 and extracellular $\mathrm{Ca}^{2+}$, and we provide insights of possible mechanisms involved in the activation of ADAM17 by BPA and NP.

\section{Results}

First, we determined that the LNCaP cell line expresses ADAM17 (Figure S1). Then, LNCaP cells were transfected with a plasmid containing a substrate of ADAM17, neuregulin 1 (NRG1), coupled to alkaline phosphatase (AP) ((AP)-NRG1), which allowed us to detect its shedding by measuring the AP activity in the cell medium [36]. There was no detection of AP activity in the culture medium of non-transfected cells when they were incubated with different concentrations of BPA or NP for $24 \mathrm{~h}$ (Figure 1A,D). However, a dramatic increase in the activity was detected when transfected cells were incubated with $100 \mu \mathrm{M}$ BPA, or with 10, 50, or $100 \mu \mathrm{M}$ NP (Figure 1B,E). The kinetics of (AP)-NRG1 shedding using $100 \mu \mathrm{M}$ BPA or $50 \mu \mathrm{M}$ NP showed that after only $3 \mathrm{~h}$ AP activity was detected in the culture medium and steadily increased up to $24 \mathrm{~h}$ of incubation (Figure 1C,F), which suggests a rapid response to these compounds. AP activity in the culture medium was not due to toxicity by plasma membrane permeabilization, since incubation with the concentrations of BPA and NP for $24 \mathrm{~h}$ used in these experiments did not increase cell trypan blue uptake (Figure S2A,B) and cell morphology was not affected (Figure S2C).

Next, we evaluated if the presence of ADAM17 was necessary to induce release of (AP)-NRG1 after BPA or NP exposure. To this end, we knocked down ADAM17 using a specific shRNA against this metalloprotease (Figure 1G,H), resulting in about $70 \%$ reduction of the mRNA and $50 \%$ at the protein ADAM17 levels using the antisense, but not scrambled shRNA. As shown before, treatment with $100 \mu \mathrm{M}$ BPA or $50 \mu \mathrm{M}$ NP stimulates a robust release of (AP)-NRG1 as compared with treatment with scrambled shRNA (Figure 1I). The knockdown of ADAM17 totally prevented the shedding of (AP)-NRG1 after treatment with $100 \mu \mathrm{M}$ BPA or $50 \mu \mathrm{M}$ NP. Interestingly, levels of (AP)-NRG1 in the culture medium were reduced in cells treated with shRNA as compared to scrambled shRNA, suggesting that in these cells the basal release of this protein depends on ADAM17. 
To further confirm these results, we transfected LNCaP cell lines with another ADAM17 substrate, TNF coupled to AP, (AP)-TNF. Results showed that $100 \mu \mathrm{M}$ BPA or $50 \mu \mathrm{M}$ NP strongly stimulated the release of (AP)-TNF and that the knockdown of ADAM17 prevented the shedding of this substrate to basal levels (Figure 1J). As showed before, shRNA treatment reduced levels of (AP)-TNF as compared to those treated with scrambled RNA, suggesting that the basal release of TNF as well as NRG1 depends upon ADAM17.

Taken together, these results strongly suggest that in vitro BPA and NP induce ADAM17 activity in LNCaP cell lines.
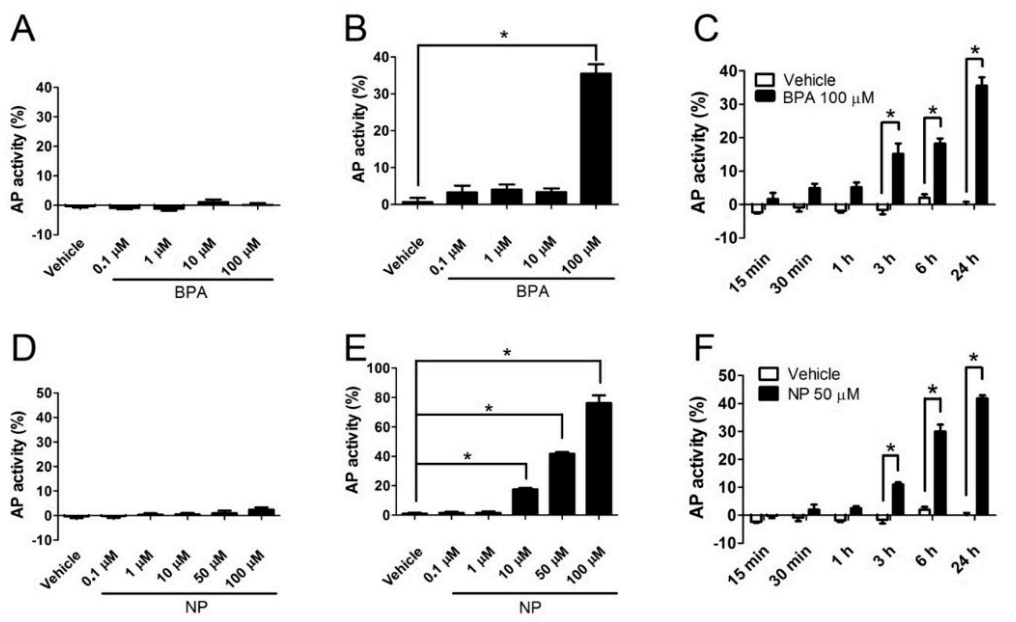

G

$\mathrm{H}$
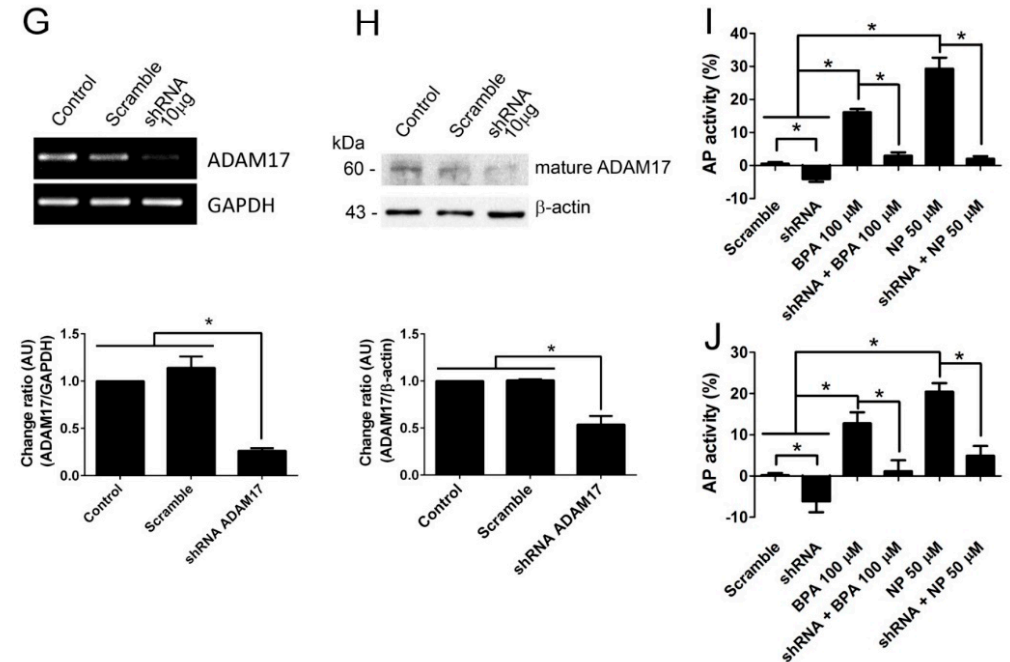

Figure 1. A Disintegrin And Metalloprotease 17 (ADAM17) sheddase activity is induced by bisphenol A (BPA) and nonylphenol (NP) in LNCaP cells transfected with alkaline phosphatase (AP)-neuregulin 1 (NGR1) vector. LNCaP cells show no detectable AP activity in culture medium when incubated with BPA (A) or NP (D) when they are not transfected with (AP)-NRG1 vector. LNCaP cells transfected with (AP)-NGR1 vector show a significant increase in culture medium when they are incubated for $24 \mathrm{~h}$ in the presence of $100 \mu \mathrm{M}$ BPA (B) or 10-100 $\mu \mathrm{M}$ NP (E). Time course of AP activity release of transfected LNCaP cells with (AP)-NRG1 vector using $100 \mu \mathrm{M}$ BPA (C) or $50 \mu \mathrm{M} \mathrm{NP}(\mathbf{F})$. Transfection of LNCaP cells with $10 \mu \mathrm{g}$ shRNA induces a robust decrease in the levels of mRNA $(\mathbf{G})$ and protein $(\mathbf{H})$ of ADAM17. Silencing of ADAM17 with $10 \mu \mathrm{g}$ shRNA in transfected LNCaP cells with (AP)-NRG1 vector (I) or (AP)-Tumor Necrosis Factor $\alpha$ (TNF) vector (J) reduces the basal levels of AP shedding and completely prevents the effect of BPA and NP. Vehicle: ethanol, mean $\pm \mathrm{SEM},{ }^{*} p<0.05, n=3$. 


\subsection{BPA and NP Induced Apoptosis in LNCaP Requires ADAM17}

Apoptosis is a type of cell death characterized by the activation of a group of cysteine-proteases named caspases, among which caspase- 3 is the major executioner of this process and proteolytically inactivates different intracellular proteins, leading to cell dismantlement [37,38]. Poly (ADP-ribose) polymerase (PARP) is one of the caspase-3 substrates belonging to a family of proteins involved in a number of cellular processes such as DNA repair and genomic stability, and its proteolysis is used as a measure of caspase-3 activation [39]. Related to this, from 15 min of $100 \mu \mathrm{M}$ BPA treatment or from $3 \mathrm{~h}$ of $50 \mu \mathrm{M}$ NP treatment, a significant increase in the number of active caspase-3-positive cells was observed in LNCaP (Figure S3). Using PARP cleavage as a criterion of caspase-3 activation, we determined that treatment with $100 \mu \mathrm{M} \mathrm{BPA}$ and $50 \mu \mathrm{M} \mathrm{NP}$, which are concentrations that stimulate the shedding of ADAM17 substrates, induces a significant increase in cleaved PARP levels (Figure 2A,B). When ADAM17 was knocked down by shRNA, the increase of cleaved PARP induced by BPA and NP was decreased significantly and reached basal levels, suggesting that BPA and NP activate apoptotic pathways in an ADAM17-dependent manner.

A
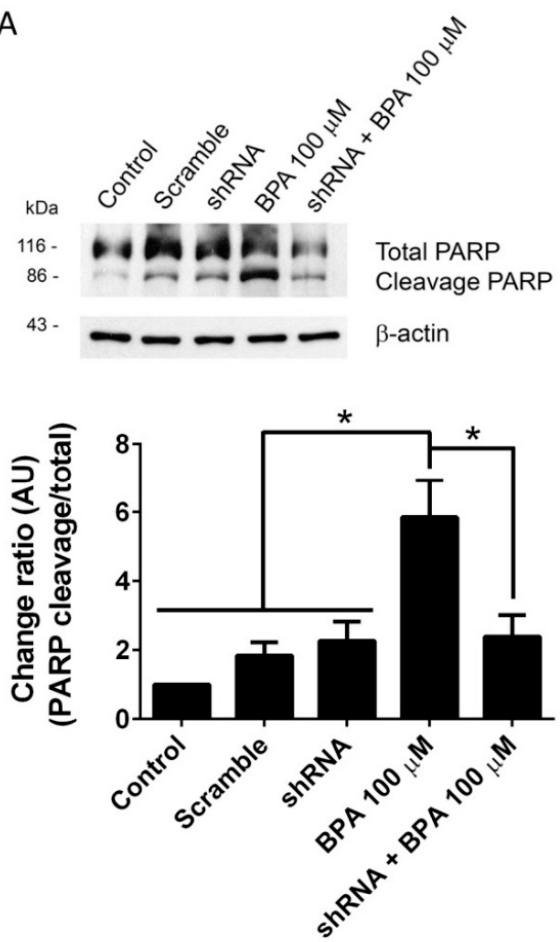

B
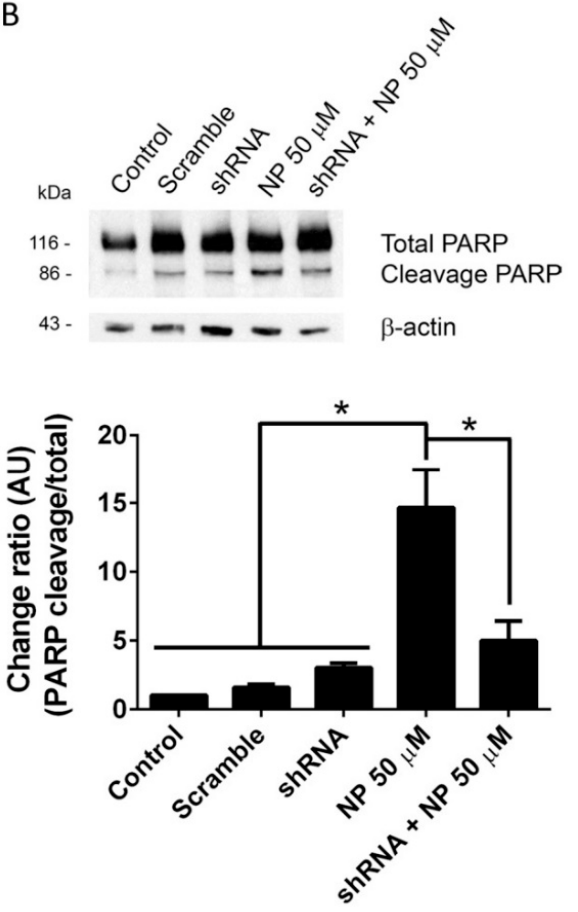

Figure 2. Silencing of ADAM17 prevents poly (ADP-ribose) polymerase (PARP) cleavage induced by BPA or NP in LNCaP cells. Treatment with $100 \mu \mathrm{M}$ BPA (A) or $50 \mu \mathrm{M}$ NP (B) for $6 \mathrm{~h}$ induces a significant increase in the cleaved form $(86 \mathrm{kDa})$ of PARP detected by Western blot. Silencing of ADAM17 with $10 \mu \mathrm{g}$ shRNA prevents the increase of the $86 \mathrm{kDa}$ form in LNCaP cells treated with BPA (A) or NP (B). Mean \pm SEM, ${ }^{*} p<0.05, n=3$.

Apoptosis was also evaluated by the sub-G1 population, which represents cells with fragmented and condensed DNA unable to fully incorporate PI. Results show that BPA and NP significantly increase the sub-G1 population, which was prevented by knocking down ADAM17 (Figure 3A,B). In addition, apoptosis was further evaluated using Annexin-V, that binds externally to phosphatidylserine, flipping to the outer plasma membrane early after apoptotic stimuli [37]. The results showed that the percentage of Annexin-V-positive cells increased after incubation with $100 \mu \mathrm{M}$ BPA or $50 \mu \mathrm{M}$ NP, and this was prevented by knocking down ADAM17 (Figure 3B). 
A

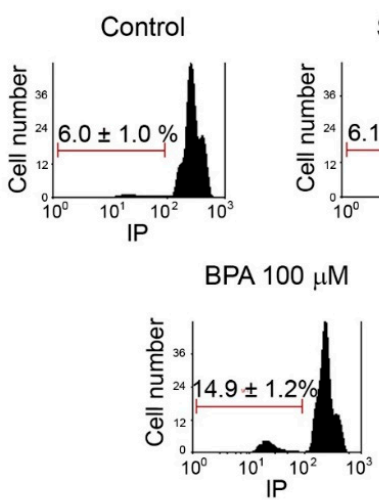

Scramble
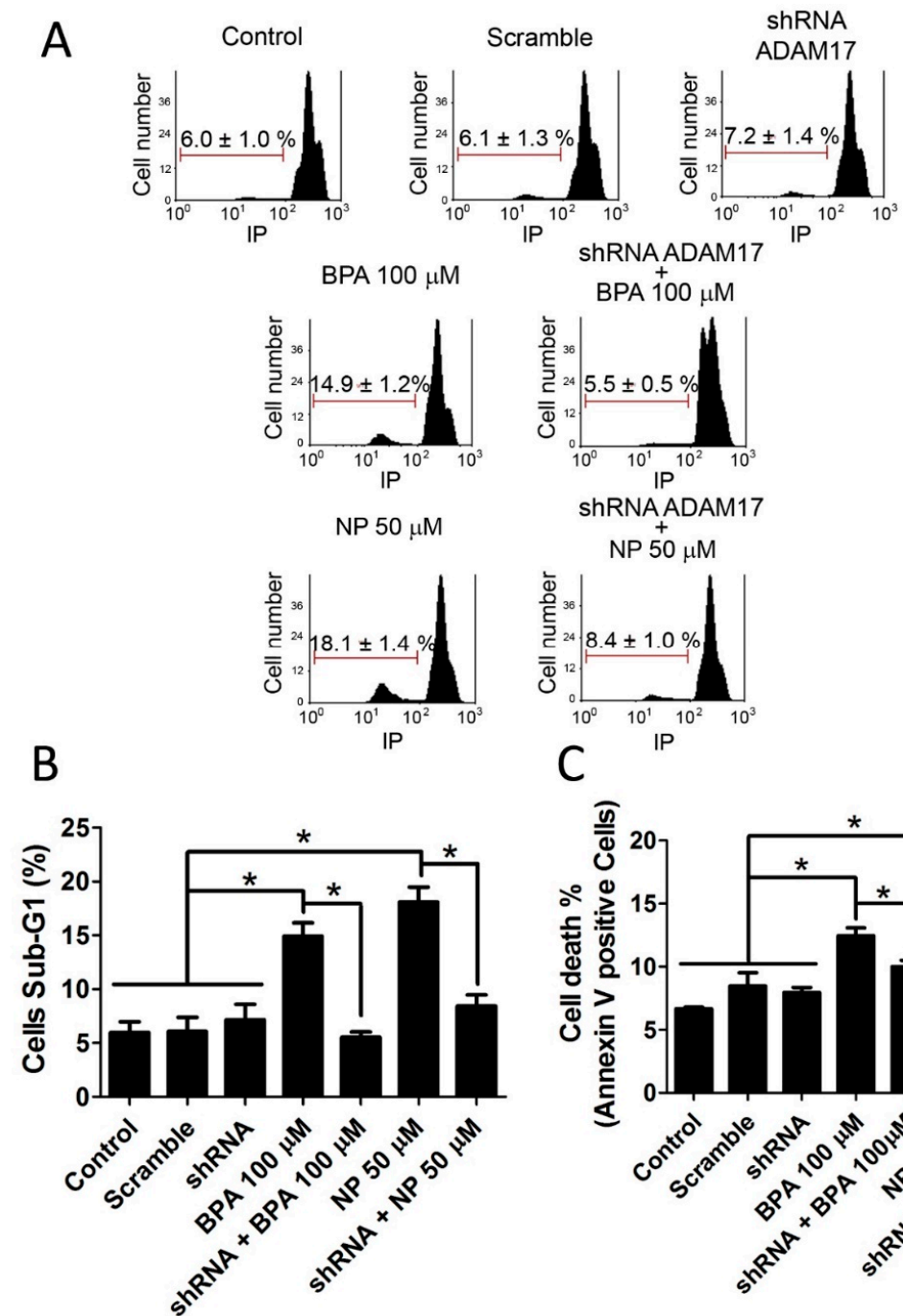

C

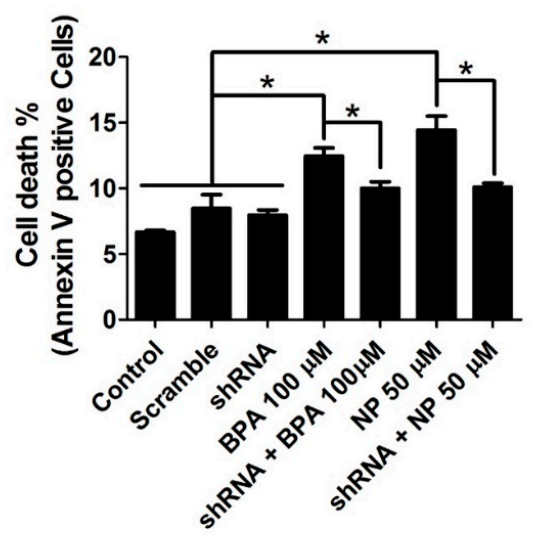

Figure 3. Silencing of ADAM17 prevents an increase in the sub-G1 population and Annexin-V-positive cells induced by BPA or NP in LNCaP cells. (A) Sub-G1 population analysis in LNCaP cells after $6 \mathrm{~h}$ of exposure to $100 \mu \mathrm{M}$ BPA or $50 \mu \mathrm{M}$ NP. Marker in each panel indicates sub-G1 cell population. ADAM17 knocked down with $10 \mu \mathrm{g}$ shRNA prevents the increase in the percentage of sub-G1 cell population (B) or Annexin-V-positive cells (C) induced by BPA or NP. Mean $\pm \mathrm{SEM},{ }^{*} p<0.05, n=3$.

To make sure that our findings were not related to a specific cell line, we used the A2780 cell line, which is derived from human ovarian carcinoma [40]. This cell line express ADAM17 and it can be also knocked down using shRNA (Figure S4). A transiently transfected A2780 cell line with (AP)-NRG1 showed increased levels of AP activity in cell culture medium (Figure 4A) and cleaved PARP when incubated with $100 \mu \mathrm{M}$ BPA or $25 \mu \mathrm{M}$ NP (Figure 4B,C). Apoptosis was confirmed by the increase in the sub-G1 population (Figure 4D) and the number of active caspase-3-positive cells (Figure 4E) observed. All these effects induced by BPA or NP were completely prevented when knocking down ADAM17 (Figure 4). Neither BPA nor NP permeabilized the A2780 cell lines, as evaluated by trypan blue intake (Figure S2D,E). They also did not affect cell morphology (Figure S2F). As a whole, these results strongly suggest that in vitro BPA and NP induce ADAM17-dependent apoptosis in at least two different cancer cell lines, LNCaP and A2780. 
A

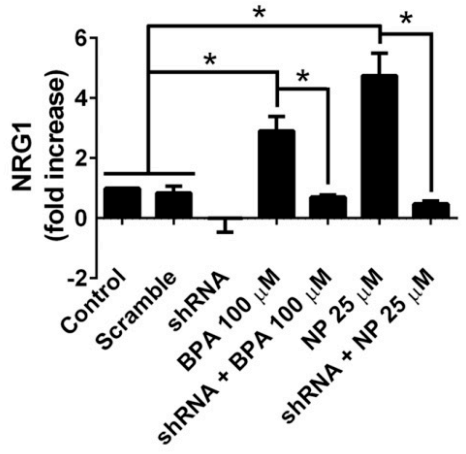

B
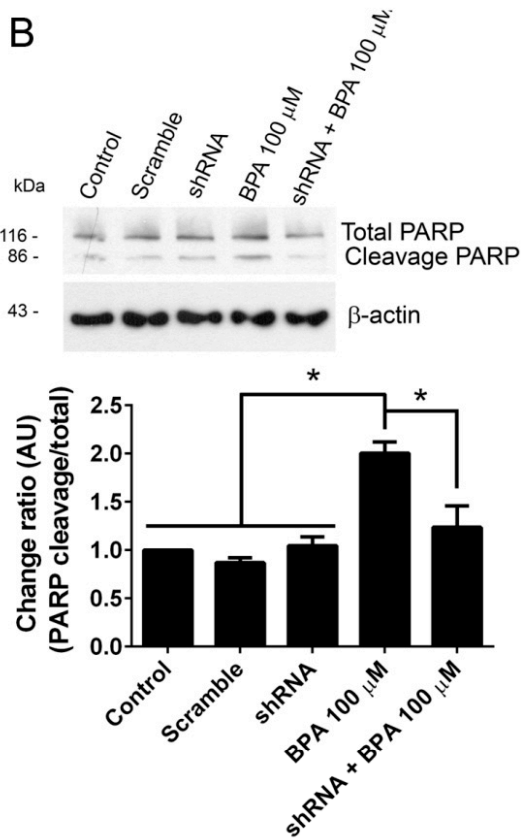

D

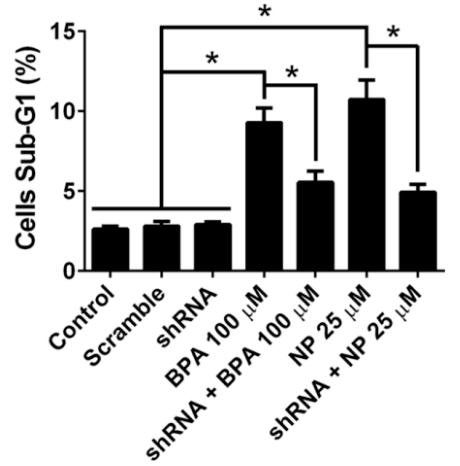

C
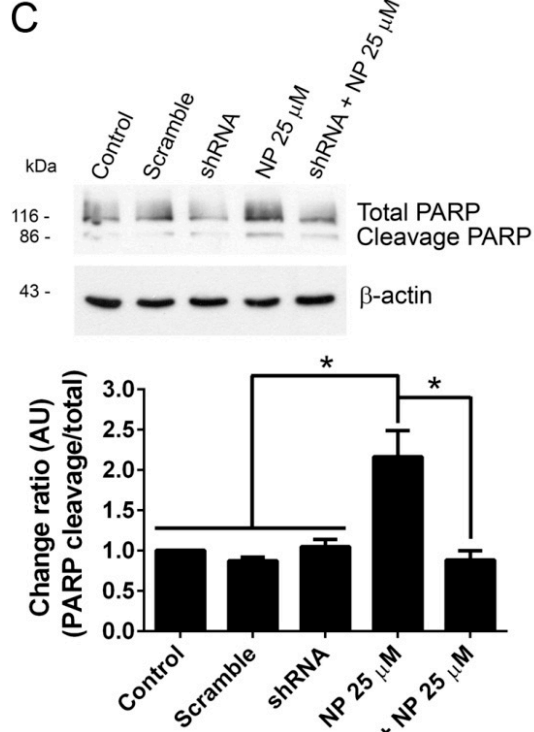

E

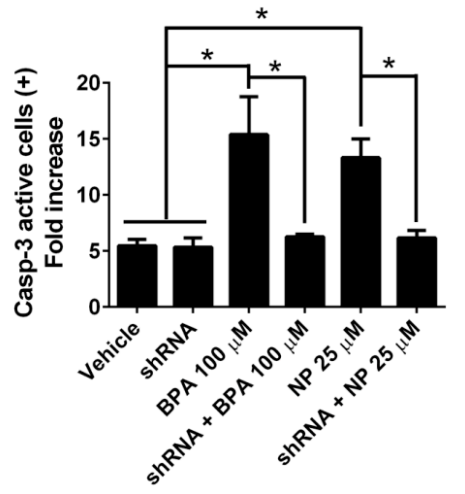

Figure 4. Silencing of ADAM17 prevents NRG1 shedding and apoptosis induced by BPA or NP in A2780 cells. (A) Shedding of NRG1 significantly increases in A2780 cells transfected with (AP)-NRG1 vector when they are incubated for $2 \mathrm{~h}$ in the presence of $100 \mu \mathrm{M}$ BPA or $25 \mu \mathrm{M}$ NP. This effect is prevented when ADAM17 is silenced by the use of $10 \mu \mathrm{g}$ shRNA. Treatment with $100 \mu \mathrm{M}$ BPA (B) or $25 \mu \mathrm{M}$ NP (C) for $2 \mathrm{~h}$ induces a significant increase in the cleaved form $(86 \mathrm{kDa})$ of PARP detected by Western blot, which was prevented when ADAM17 was silenced with $10 \mu \mathrm{g}$ shRNA. Treatment with $100 \mu \mathrm{M}$ BPA or $25 \mu \mathrm{M}$ NP for $2 \mathrm{~h}$ induces a significant increase in the sub-G1 population (D) and cleaved caspase-3-positive cells of A2780 cells line (E), which were prevented when ADAM17 was knocked down with $10 \mu \mathrm{g}$ shRNA. Mean $\pm \mathrm{SEM},{ }^{*} p<0.05, n=3$. 


\subsection{Pathways Activated by BPA and NP}

It is known that BPA and NP induce an increase in the $\left.\mathrm{Ca}^{2+}\right]_{i}$ in different cell types $[22,23]$. Specifically, $100 \mu \mathrm{M}$ BPA or $50 \mu \mathrm{M}$ NP induced a fast and sustained increase in $\left[\mathrm{Ca}^{2+}\right]_{i}$, which was not observed in $\mathrm{Ca}^{2+}$-free medium or after vehicle treatment (Figure 5A,B). LNCaP cells transiently transfected with (AP)-NRG1 showed a robust increase in AP activity after incubation with $100 \mu \mathrm{M}$ BPA or $50 \mu \mathrm{M} \mathrm{NP}$ in a $\mathrm{Ca}^{2+}$-free medium (Figure 5C, white bars). The shedding of (AP)-NRG1 after $100 \mu \mathrm{M}$ BPA was not significantly affected by extracellular $\mathrm{Ca}^{2+}$ (Figure 5C). However, the shedding of (AP)-NRG induced by NP was potentiated in $\mathrm{Ca}^{2+}$-containing medium (Figure $5 \mathrm{C}$, compare white and black bars), suggesting that a greater effect of NP relies on extracellular $\mathrm{Ca}^{2+}$. These results show that in the absence of extracellular $\mathrm{Ca}^{2+}, \mathrm{BPA}$ and NP induce similar ADAM17 sheddase activity, but only NP-induced activity is potentiated by extracellular $\mathrm{Ca}^{2+}$, probably by increasing $\left[\mathrm{Ca}^{2+}\right]_{\mathrm{i}}$.

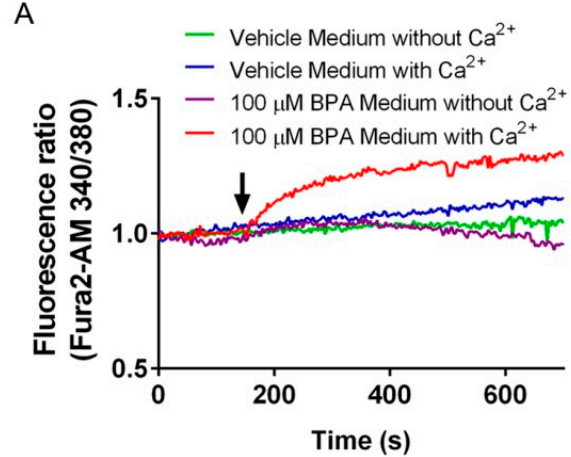

C
B

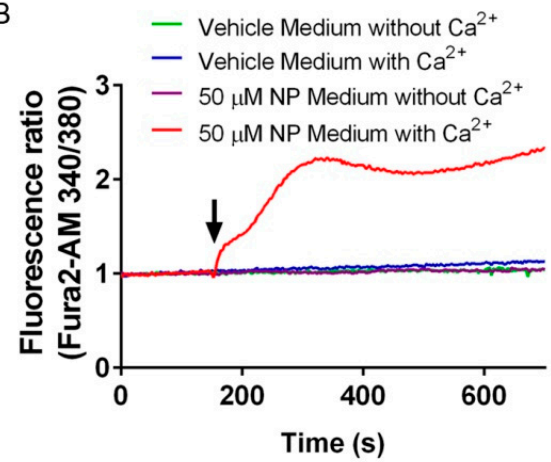

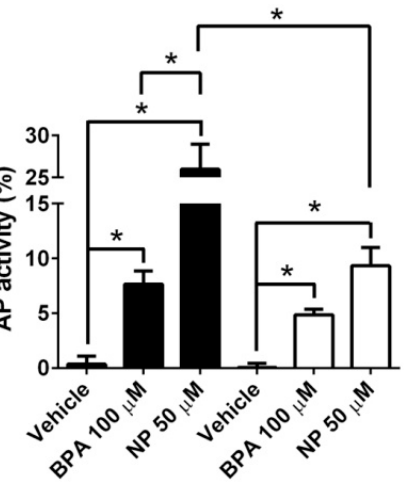

Medium with $\mathrm{Ca}^{2+}$

$\square$ Medium without $\mathrm{Ca}^{2+}$

Figure 5. Participation of calcium $\left(\mathrm{Ca}^{2+}\right)$ on the sheddase activity induced by BPA and NP in LNCaP cells. Intracellular $\mathrm{Ca}^{2+}$ levels after $100 \mu \mathrm{M}$ BPA (A) or $50 \mu \mathrm{M}$ NP (B) treatment in a medium with or without $\mathrm{Ca}^{2+}$. (C) Shedding of NRG1 in (AP)-NRG1 transfected LNCaP cells, when they are incubated for $3 \mathrm{~h}$ in the presence of $100 \mu \mathrm{M}$ BPA or $50 \mu \mathrm{M} \mathrm{NP}$, in a medium with (black bars) or without (white bars) $\mathrm{Ca}^{2+}$. Mean $\pm \mathrm{SEM},{ }^{*} p<0.05, n=5$.

In an attempt to elucidate the intracellular signaling pathways elicited by BPA and NP in LNCaP cells, we took advantage of a human phospho-kinase antibody array that detects changes in the phosphorylation state of 43 signaling-related phosphoproteins (Table S1). We found that after a 15-min treatment with $100 \mu \mathrm{M}$ BPA or $50 \mu \mathrm{M}$ NP, 20 and five protein kinases out of these 43 phosphoproteins detected by the antibody array (Table S1), respectively, showed at least 2-fold increased protein levels, as compared with the vehicle (Figure 6). Interestingly, all five kinases activated by NP were also activated by BPA, and corresponded to PLC- $\gamma 1$, eNOS, STAT5a/b, PRAS40, and c-Jun (Figures 6 and 7). 

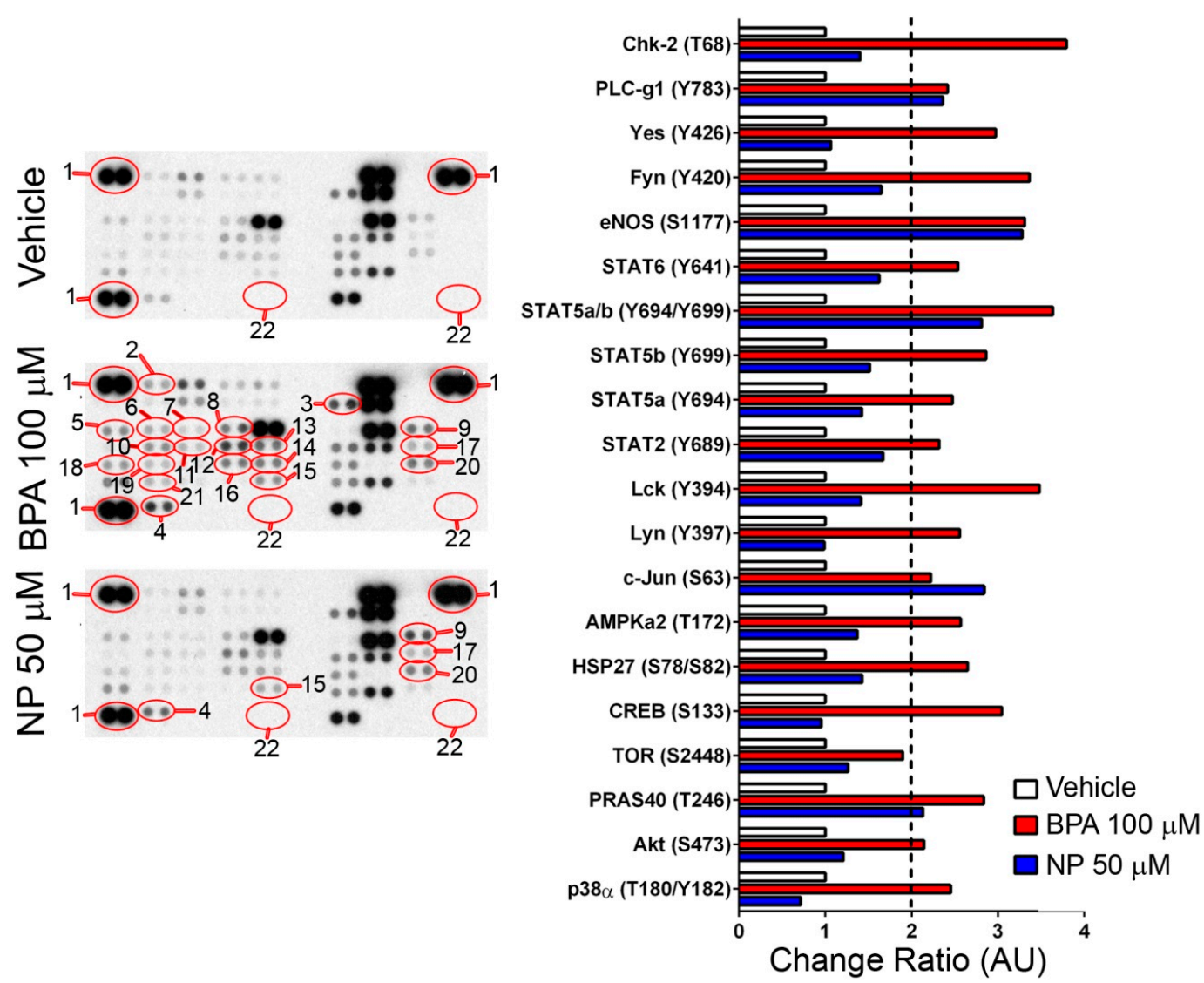

Figure 6. BPA or NP induces an increase in the phosphorylation of protein kinases analyzed by a human phospho-kinase antibody array. LNCaP treated with $100 \mu \mathrm{M}$ BPA or $50 \mu \mathrm{M}$ NP for 15 min shows an increase of several protein kinases. The graph shows the quantification of the pixels density shown in the left panel. The kinases selected were those whose change ratio was at least two times higher compared to those observed in the vehicle treatment (ethanol). (1) Reference spot, (2) p38 $\alpha$ (T180/Y182), (3) Akt (S473), (4) PRAS40 (T246), (5) TOR (S2448), (6) CREB (S133), (7) HSP27 (S78/S82), (8) AMPKa2 (T172), (9) c-Jun (S63), (10) Lyn (Y397), (11) Lck (Y394), (12) STAT2 (Y689), (13) STAT5a (Y694), (14) STAT5b (Y699), (15) STAT5a/b (Y694/Y699), (16) STAT6 (Y641), (17) eNOS (S1177), (18) Fyn (Y420), (19) Yes (Y426), (20) PLC- $\gamma 1$ (Y783), (21) Chk-2 (T68), and (22) negative control (PBS).

It was observed that BPA activated pathways related to the G-protein coupled receptors, tyrosine kinase receptors, and pathways activated by cell damage (Figure 7A). The PLC $\gamma 1$, AMPK $\alpha 2$, and eNOS proteins participated in the GPCRs pathways inducing cell adhesion and cell migration [41-47] (Figure 7A). The kinases Akt, Lyn, Lck, Yes, Fyn PRAS40, TOR, CREB, c-Jun, STAT5a, STAT5b, and the dimers STATa /b, 2 and 6 were activated mostly by tyrosine kinase receptors participating in cell growth, cell differentiation, and cell survival pathways [48-59] (Figure 7A). Finally, the kinases p38 $\alpha$, Hsp27, and Chk-2 were activated by cell damage in the form of heat stress and treatments with anticancer drugs that induce apoptosis [60-63] (Figure 7A). On the other hand, a treatment with NP for 15 min mainly activated the cell adhesion and cell migration pathways due to the phosphorylation of PLC $\gamma 1$ and eNOS, probably by GPCRs mediated pathways, and activated the tyrosine kinase receptors due to the phosphorylation of STAT5a/b, PRAS40, and c-jun participating in cell growth, cell differentiation, and cell survival pathways $[41-43,47,49,50,54,55]$ (Figures 6 and 7B). Taken together, these results suggest that BPA and NP elicit different intracellular signaling pathways that could lead to ADAM17 sheddase activation. 

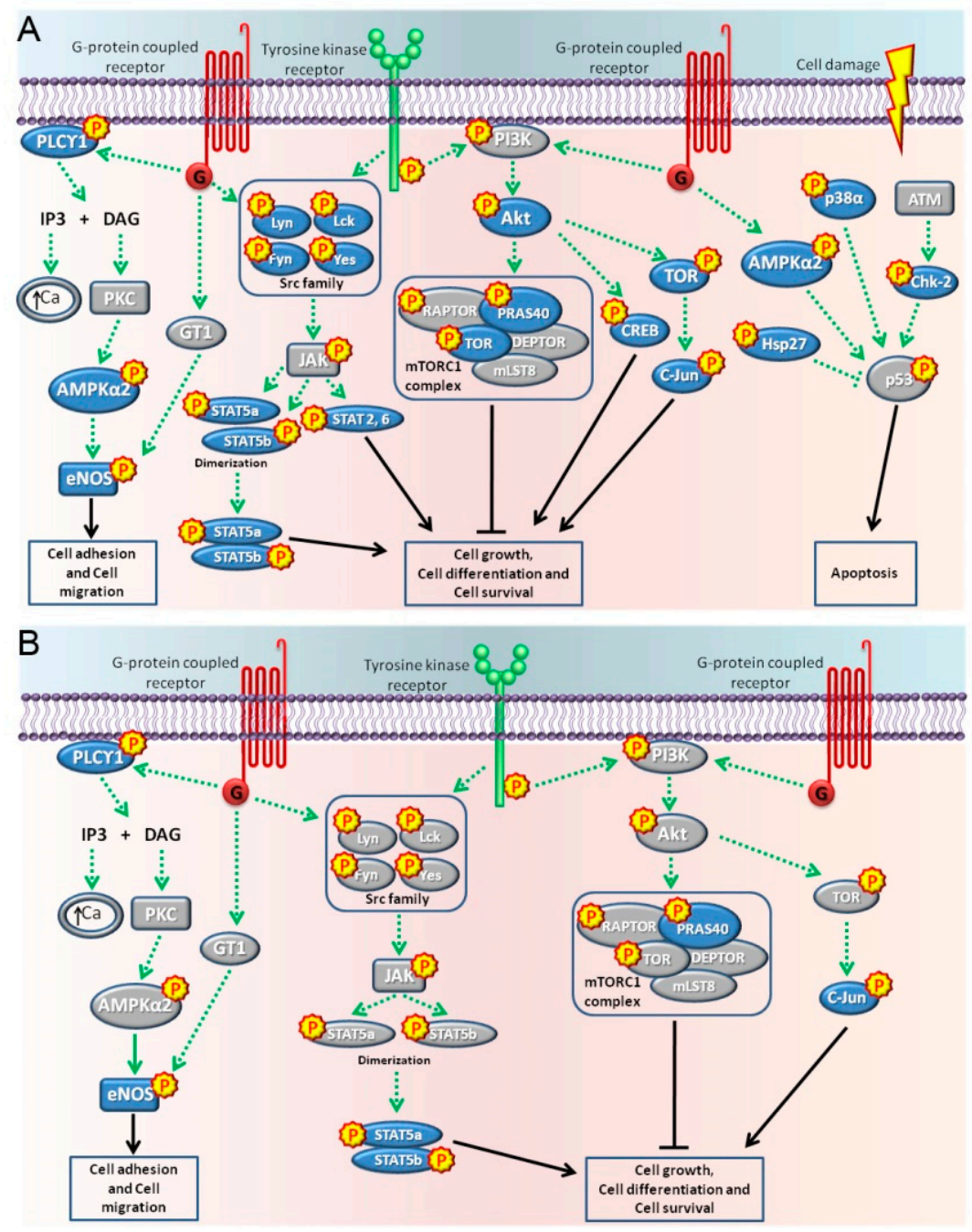

Figure 7. Diagram of possible signaling pathways induced by a 15-min treatment with BPA (A) or NP (B) in LNCaP cells. BPA mainly activated G protein-coupled membrane receptors and tyrosine kinase receptors or cellular damage pathways (A), while NP mainly activated G protein-coupled membrane receptors and tyrosine kinase receptor pathways $(\mathbf{B})$. The phosphorylated proteins participating in pathways of: cell adhesion and cell migration, cell growth, cell differentiation and cell survival, and apoptosis. In blue are shown proteins that increase their levels of phosphorylation as a result of the treatment, while in gray are shown proteins that were analyzed did not show a significantly increase in phosphorylation.

\section{Discussion}

Previous work in cultured cells have shown that BPA and NP induce apoptosis in different cell types $[23,25,28,29,34]$. On the contrary, low concentrations (nM or pM) of BPA and NP induce cell proliferation in transformed and non-transformed cells [64-66]. Here, we report that BPA and NP, at concentrations similar to those found in the urine of humans exposed to high concentrations of these EDCs, such as plastic factory workers, who are exposed up to 500 times higher levels of these compounds than the general population [67], induce apoptosis in prostate (LNCaP) and ovary (A2780) cancer-derived human cell lines. Our experimental strategy included four different approaches to establish that, in vitro, concentrations of $100 \mu \mathrm{M}$ BPA or $50 \mu \mathrm{M}$ NP effectively induce apoptosis in two different cancer cell lines. Our previous findings have suggested that, in vivo, BPA and NP induce germ cell apoptosis by a mechanism that involves the activation of the metalloprotease ADAM17 [23]. 
Here, we show that, in vitro, BPA- and NP-induced apoptosis could be prevented by knocking down ADAM17, suggesting that this enzyme is important in the mechanism elicited by these compounds to induce cell death. Interestingly, the concentrations that induce cell death are the same as those that stimulate the release of ADAM17 substrates (TNF and NRG1), suggesting that the shedding of ADAM17 substrates might be connected to the induction of apoptosis. In this way, it is possible that the mechanisms involved in the shedding of ADAM17 substrates, or the substrates released after the stimulus, could participate in the elicitation of apoptosis in an auto/paracrine pathway.

It is possible that substrates such as TNF or FAS ligand (FASL) could bind to its cognate receptor in an auto/paracrine way and stimulate apoptosis only in a particular group of cells expressing these receptors or in a specific stage of the cell cycle. Interestingly, it has been documented that nonylphenol-induced apoptosis in a human embryonic stem cell and two human bronchial epithelial cell lines is related to the FASL/FAS system [68]. This hypothesis could explain the fact that no more than $20 \%$ of the exposed cells undergo apoptosis.

It has been reported that BPA at low concentrations causes an increase in epidermal growth factor receptor (EGFR) activation and the downstream ERK pathway in inflammatory breast cancer cells, which is associated with increased cell proliferation [69]. In the same way, BPA and NP stimulate the release of EGFR ligands, such as TGF $\alpha$ or HB-EGF, by activating either ADAM17 or ancillary proteins such as iRhom1 and/or iRhom2 [22,70]. The activation of EGFR by BPA was also observed in LNCaP cells, which leads to the activation of the main cellular regulator p53 [71]. Here, we show that BPA or NP activate a set of phosphoproteins participating in different intracellular pathways involved in cell death, proliferation, and differentiation. However, interestingly, p53 was one of the proteins that was not affected by either treatment. The activation of p53 appears to be a late effect of BPA treatment, which is observed after $24 \mathrm{~h}$ [71]. In our experiments, BPA and NP induce apoptosis at 6 $\mathrm{h}$, which could explain the absence of this protein in our phosphoprotein microarray. BPA activates more phosphoproteins than NP, suggesting that the former has a wider range of effects in different cell contexts than the latter. Interestingly, we found that all of the phosphoproteins that increased protein levels after NP treatment were also increased after BPA treatment, suggesting that both compounds share some signaling pathways. Since both compounds activate the shedding of ADAM17 substrates, we suggest that it is possible that two of the common activated phosphoproteins-c-Jun and Stat $5 \mathrm{a} / \mathrm{b}$ - could explain these effects. In fact, it has been observed that the modulation of c-Jun or Stat5a activation also modulates TNF shedding elicited by BPA and NP in cancer cell lines [72-74]. However, it remains to be investigated whether the activation of the phosphoproteins observed in the present study is due to a direct activation of BPA and NP or whether this activation is achieved indirectly, by the shedding and auto/paracrine activation of cognate receptors, which seems to be the case of BPA [69].

Finally, we confirmed previous results showing that BPA and NP induce a rise in $\left[\mathrm{Ca}^{2+}\right]_{\mathrm{i}}$, which depends upon the presence of extracellular $\mathrm{Ca}^{2+}$. This effect could be related to the different $\mathrm{Ca}^{2+}$ channels that are activated by either of these compounds in different cell types [31-33,75,76]. Interestingly, the ADAM17 activation induced by NP was higher than that induced by BPA in $\mathrm{Ca}^{2+}$-containing medium, but in a $\mathrm{Ca}^{2+}$-free medium BPA- and NP-induced ADAM17 sheddase activity was similar, demonstrating that both compounds have a similar basal effect. In this context, it is interesting that we detected that BPA and NP activate PLC $\gamma$, which produces the second messengers $\mathrm{IP}_{3}$ and DAG, which open intracellular $\mathrm{Ca}^{2+}$ stores and subsequently may activate PKC. However, it is possible that under our experimental conditions, activated PLC $\gamma$ reached levels below the activation threshold to produce enough $\mathrm{IP}_{3}$ in order to open the intracellular $\mathrm{Ca}^{2+}$ stores, which could explain the absence of $\mathrm{Ca}^{2+}$ signals when cells were treated in a $\mathrm{Ca}^{2+}$-free medium.

The present results extend our previous observations that BPA- and NP-induced germ cell apoptosis requires ADAM17 activation, suggesting a general mechanism of cell toxicity for these EDCs that may also include extracellular $\mathrm{Ca}^{2+}$ as a potentiator of the effect. 


\section{Materials and Methods}

\subsection{Chemicals and Antibodies}

Bisphenol A [2,2-bis (4-hydroxyphenyl) propane] (BPA) (239658) and nonylphenol (NP) (442873) were obtained from Sigma (St. Louis, MO, USA). LipofectAMINE 2000 (11668-027), p-nitrophenyl phosphate (p-NPP) (002212), substrate of alkaline phosphatase, TRIzol-Reagent (15596026), FURA2-AM (F1221), and propidium iodide (P1304MP) were obtained from Invitrogen (Carlsbad, CA, USA). BB-94 (Batimastat) (196440) was obtained from Calbiochem (San Diego, CA, USA). ADAM17 antibody (ab39163) was purchased from Abcam (Cambridge, MA, USA). PARP-1/2 antibody (sc-7150) was purchased from Santa Cruz Biotechnology (Santa Cruz, CA, USA). Cleaved Caspase-3 (Asp175) antibody (\#9661) was acquired from Cell Signaling (Danvers, MA, USA). $\beta$-actin (AC-15) and anti-rabbit IgG-FITC (F0382) antibodies were purchased from Sigma (St. Louis, MO, USA). Peroxidase anti-mouse IgG (5220-0286) and peroxidase anti-rabbit IgG (5220-0283) antibodies were obtained from KPL (Gaithersburg, MD, USA). Human phospho-kinase antibody array (Catalog \#ARY003B) was obtained from R\&D Systems (Minneapolis, MN, USA). Western Lightning Chemiluminescense Reagent Plus kit (NEL104001EA) was obtained from PerkinElmer Inc. (Waltham, MA, USA).

\subsection{Cell Transfection and Generation of a Stable Cell Line}

LNCaP was kindly donated by Dr. Alejandro Godoy from Pontificia Universidad Católica de Chile (Santiago, Chile), and A2780 was kindly donated by Dr. Gareth Owen from Pontificia Universidad Católica de Chile (Santiago, Chile). Both cell lines were transfected with the plasmid (AP)-NRG1 or (AP)-TNF [36,77], kindly donated by Dr. Carl Blobel (Hospital for Special Surgery, New York, NY, USA), or with the shRNA against the ADAM17 mRNA (KH00343N, Qiagen Sicences, MD, USA), which was purchased from Qiagen (Hilden, Germany). Briefly, LNCaP and A2780 cells, after being seeded to $80 \%$ confluence for $12 \mathrm{~h}$, were washed and cultured in DMEM-F12 medium (12400-024, Gibco, Life Technologies, Carlsbad, CA, USA) deprived of serum, antibiotic, and antimycotic for $1 \mathrm{~h}$. Following that, the cells were cultured for $6 \mathrm{~h}$ with a complex DNA-LipofectAMINE 2000, and finally the cells were cultured for $24 \mathrm{~h}$ in DMEM-F12 medium with 10\% Fetal Bovine Serum (FBS) (04-127-1A, Biological Industries, Beit Haemek, Israel) and 10\% antibiotic and antimycotic (15240-062, Gibco, Life Technologies, Carlsbad, CA, USA). The transfection was evaluated by the presence of NRG1 or the decrease of ADAM17 mRNA levels by RT-PCR.

The generation of LNCaP cell lines that stably expressed (AP)-NRG1 was obtained by the incubation of the transfected cells with $200 \mu \mathrm{g} / \mathrm{mL}$ of antibiotic zeocin (R25001, Invitrogen, Carlsbad, CA, USA).

\subsection{Alkaline Phosphatase Activity Measurement}

LNCaP cells stably transfected with (AP)-NRG1 were washed once in PBS and incubated for $1 \mathrm{~h}$ in DMEM-F12 (nonstimulated conditioned medium) and then in DMEM-F12 containing BPA or NP at different concentrations and for different times (stimulated conditioned medium). Conditioned media were collected and incubated for $1 \mathrm{~h}$ with p-NPP (p-nitrophenyl phosphate) (4:1), a colorimetric and soluble AP substrate, and then the AP activity was measured by a spectrophotometer at $405 \mathrm{~nm}$. Each experiment was conducted at least three times. For the A2780 cells, the day following transfection, each well was washed once in PBS and incubated for $1 \mathrm{~h}$ in DMEM-F12 (nonstimulated conditioned medium) and then in DMEM-F12 containing BPA or NP at different concentrations for $2 \mathrm{~h}$ (stimulated conditioned medium). Conditioned media were collected and cells were lysed in PBS containing 1\% Triton X-100 (T8787, Sigma, St. Louis, MO, USA) plus a general metalloprotease inhibitor, BB-94 $10 \mu \mathrm{M}$, and protease inhibitor cocktail (P2714, Sigma, St. Louis, MO, USA) including $2 \mathrm{mM}$ AEBSF [4-(2-Aminoethyl) benzenesulfonylfluoride hydrochloride], $0.3 \mu \mathrm{M}$ aprotinin, $130 \mu \mathrm{M}$ bestatin hydrochloride, $14 \mu \mathrm{ME}-64,1 \mathrm{mM}$ EDTA, and $1 \mu \mathrm{M}$ leupeptin hemisulfatein. Alkaline phosphatase activity measure was performed as previously published [22]. Briefly, conditioned media and cells lysate were incubated for $1 \mathrm{~h}$ with p-NPP (p-nitrophenyl phosphate) (1:1 and 0.1:1, respectively), 
and then the AP activity was measured by a spectrophotometer at $405 \mathrm{~nm}$. All experiments were conducted in triplicates, and the transfection efficiency was measured by the ratio of AP activity in the medium to that of the cell lysate plus the medium. The fold increase in the ratio of AP activity obtained after our treatments is shown relative to the ratio of AP activity in untreated control wells, which represents the baseline of each graph (value 0 in the $Y$ axis in each graph). In this way, all values are normalized by untreated controls and each value in the graphs represents whether the AP activity was above or below this control.

\subsection{Protein Extraction and Western Blotting}

Protein extraction and Western blotting were performed as previously published [23]. Briefly, the homogenization of cells was performed in a buffer containing $1 \mathrm{M} \mathrm{NaCl}, 1 \mathrm{mM}$ EDTA, $10 \mathrm{mg} / \mathrm{mL}$ PMSF, $1 \%$ Triton X-100, and 20mM Tris- $\mathrm{HCl} \mathrm{pH} \mathrm{7.4,} \mathrm{plus} \mathrm{a} \mathrm{general} \mathrm{metalloprotease} \mathrm{inhibitor,} \mathrm{BB-94}$ $10 \mu \mathrm{M}$, and protease inhibitor cocktail (Sigma), and then centrifuged for $10 \mathrm{~min}$ at $10,000 \times g$ at $4{ }^{\circ} \mathrm{C}$. Then, samples were run on a $10 \%$ polyacrylamide gel under reducing and denaturing conditions, transferred to nitrocellulose at $400 \mathrm{~mA}$ for $1 \mathrm{~h}$, and blocked with $3 \%(w / v)$ non-fat milk, $0.1 \%$ Tween in TBS, pH 7.4. Primary antibodies were incubated overnight at $4{ }^{\circ} \mathrm{C}$ with the following dilutions: anti-ADAM17 and anti-PARP-1/2 $(0.2 \mu \mathrm{g} / \mathrm{mL})$, or anti- $\beta$-actin $(0.3 \mu \mathrm{g} / \mathrm{mL})$. A secondary antibody conjugated with horseradish peroxidase $(0.3 \mu \mathrm{g} / \mathrm{mL})$ (KPL, Gaithersburg, MD, USA) was used. Protein bands were developed using the Western Lightning Chemiluminescense Reagent Plus kit (PerkinElmer Inc, Waltham, MA, USA).

\subsection{RNA Extraction and RT-PCR}

RNA extraction and PCR were performed as previously reported [23]. Briefly, RNA of LNCaP and A2780 cells was extracted with TRIzol-Reagent (Invitrogen, Carlsbad, CA, USA). Then, cDNA was generated from $1 \mu \mathrm{g}$ RNA using random primers and Reverse Transcriptase (Promega, Madison, WI). PCR was performed using the PCR Master Mix (Promega). Primer sets: ADAM17 forward $5^{\prime}$-GTTGGTGAGCCTGACTCTA- $3^{\prime}$ and reverse $5^{\prime}$-CCTCTTGTGGAGACTTGA- ${ }^{\prime}$; NRG1 forward $5^{\prime}$-ATCCACGACTGGGACCAG-3' and reverse $5^{\prime}$-AAGCTTCTGCCGCTGTTTC-3'; GAPDH forward $5^{\prime}$-TCCACCACCCTGTTGCTGTA-3' and reverse $5^{\prime}$-ACCACAGTCCATGCCATCAC- $3^{\prime}$. PCR products were run in a $1 \%$ agarose gel and then stained with $\mathrm{SYBR}^{\circledR}$ Green (Invitrogen, Carlsbad, CA, USA). The pixel density of each band was measured and normalized to GAPDH mRNA levels.

\subsection{Sub-G1 Population Analysis by Flow Cytometry}

After treatment, LNCaP and A2780 cells were fixed in 70\% ethanol. The cells were then pelleted and washed once with PBS. Then, the pellet was dissolved in a buffer containing $0.1 \%$ sodium citrate, $0.3 \%$ Triton X-100 (Sigma), $50 \mathrm{mg} / \mathrm{mL}$ propidium iodide, and $50 \mathrm{mg} / \mathrm{mL}$ RNase A (Invitrogen, Carlsbad, CA, USA). The samples were then analyzed by a flow cytometer (FAScanto, BD Biosciences, Franklin Lakes, NJ, USA). Ten thousand gated events were acquired in each sample. All data were analyzed with software FCS express V4.0 (De Novo Software, Los Angeles, CA, USA).

\subsection{Annexin-V Assay}

LNCaP cells treated with $100 \mu \mathrm{M}$ BPA or $50 \mu \mathrm{M}$ NP for $6 \mathrm{~h}$ were washed twice with PBS. After that, they were incubated with $5 \mu \mathrm{L}$ of FITC-Annexin- $\mathrm{V}$ and $5 \mu \mathrm{L}$ of propidium iodide for 15 min at room temperature in the dark. Then, $400 \mu \mathrm{L}$ of binding buffer was added and analyzed by flow cytometry (FAScanto, BD Biosciences, Franklin Lakes, NJ, USA) and 10,000 gated events were acquired in each sample. All data were analyzed with software FCS express V4.0 (De Novo Software, Los Angeles). 


\section{8. $\left[\mathrm{Ca}^{2+}\right]_{i}$ Measurements of LNCaP Cells in Suspension}

LNCaP cells were grown on 10-cm plates for $24 \mathrm{~h}$. After that, they were washed with PBS and then incubated with EDTA $5 \mathrm{mM}$ for $15 \mathrm{~min}$ at $37^{\circ} \mathrm{C}$. LNCaP cells were resuspended $\left(20 \times 10^{6}\right.$ cells $\left./ \mathrm{mL}\right)$ in Locke medium ( $\mathrm{NaCl} 130 \mathrm{mM}, \mathrm{Ca} 2 \mathrm{Cl} 2.3 \mathrm{mM}, \mathrm{KCl} 5.6 \mathrm{mM}$, Hepes $8.4 \mathrm{mM}, \mathrm{Mg} 2 \mathrm{Cl} 1 \mathrm{mM}$, glucose $5.6 \mathrm{mM}$ ). The cells in Locke medium were loaded with $5 \mu \mathrm{M}$ of the $\mathrm{Ca}^{2+}$ probe Fura-2 AM by incubation for $30 \mathrm{~min}$ at $37^{\circ} \mathrm{C}$, followed by three washes with Locke medium with $\mathrm{Ca}^{2+}$ or Locke medium without $\mathrm{Ca}^{2+}(\mathrm{NaCl} 130 \mathrm{mM}, \mathrm{KCl} 5.6 \mathrm{mM}$, Hepes $8.4 \mathrm{mM}, \mathrm{Mg} 2 \mathrm{Cl} 1 \mathrm{mM}$, glucose $5.6 \mathrm{mM}$, EGTA $1 \mathrm{mM})$. The fluorescence measurements were performed by adding a concentrated cell suspension $(50 \mu \mathrm{L})$ to a temperature-regulated spectrofluorimeter cuvette $(3.0 \mathrm{~mL}$, with stirring) containing $2.5 \mathrm{~mL}$ of Locke medium with or without $\mathrm{Ca}^{2+}$. The $\left[\mathrm{Ca}^{2+}\right]_{\mathrm{i}}$ determinations were carried out using a radiometric method described before [78].

\subsection{Human Phospho-Kinase Array}

The assays were performed using LNCaP cells treated with $100 \mu \mathrm{M}$ BPA or $50 \mu \mathrm{M}$ NP for $15 \mathrm{~min}$ according to the manufacturer's protocol (R\&D Systems, Minneapolis, USA, Cat: ARY003B). Spots obtained were analyzed measuring the pixel density with Adobe Photoshop 7.0 (Adobe System Incorporated, San Jose, CA, USA). A protein was considered to be upregulated when its spot density was at least 2-fold higher than the corresponding spot observed in the vehicle treatment.

\subsection{Immunohistochemistry and Immunofluorescence}

Active caspase-3 was detected in LNCaP cells seeded on 12-mm cover glasses at $80 \%$ confluence and fixed in paraformaldehyde $4 \%$. Samples were first treated with $3 \% \mathrm{H}_{2} \mathrm{O}_{2}$ for $10 \mathrm{~min}$, and then incubated with a standard protein block system (Ultra V block, Thermo Scientific, Fremont, CA, USA) for $10 \mathrm{~min}$. Primary rabbit polyclonal antibody against cleaved caspase-3 (Asp175) (\#9661, Cell Signaling, Danvers, MA, USA) was applied at a dilution of 1:250 in 3\% BSA in TBS containing $0.1 \%$ Tween-20; samples were then incubated overnight at $4{ }^{\circ} \mathrm{C}$. Biotinylated secondary antibody, and peroxidase-conjugated streptavidin were applied for $10 \mathrm{~min}$ (Thermo Scientific, Fremont, CA, USA). Cover glasses were washed three times for $5 \mathrm{~min}$ in Tris- $\mathrm{HCl}$ buffer, $\mathrm{pH} 7.6$, with $0.3 \mathrm{M} \mathrm{NaCl}$ and $0.1 \%$ Tween-20. For final staining, DAB (3,3-diaminobenzidine tetrahydrochloride) plus substrate and chromogen (Thermo Scientific, Fremont, CA, USA) were applied for $1 \mathrm{~min}$. After washing with distilled water, samples were counter-stained with hematoxylin and observed under a phase contrast microscope (Optiphot-2, Nikon, Tokyo, Japan) and photographed with a digital camera (CoolPix 4500, Nikon, Tokyo, Japan). For immunofluorescence, a similar protocol was applied. Briefly, after fixation, permeabilization, and blocking with BSA 3\%, cells were stained with anti-ADAM17 antibody for $1 \mathrm{~h}$ at room temperature. Then, anti-rabbit FITC at $4 \mu \mathrm{g} / \mathrm{mL}$ diluted in 3\% BSA was applied and incubated for another $1 \mathrm{~h}$ at room temperature. After washing three times with TBS-Tween-20, nuclei were stained with propidium iodide, and finally the slides were mounted with fluoromount (Sigma, St. Louis, MO, USA) and observed under a microscope (Zeiss LSM-510, Oberkochen, Germany).

\subsection{Statistical Analysis}

For mean comparisons, we used analysis of variance (ANOVA). When the ANOVA test showed statistical differences, the Tukey post hoc test was used to discriminate between groups. Statistical significance was defined as $p<0.05$ [79]. Statistical analyses were performed using GraphPad Prism version 5.0 for Windows (GraphPad Software, San Diego, CA, USA, www.graphpad.com). 
Supplementary Materials: Supplementary materials can be found at http:/ /www.mdpi.com/1422-0067/19/8/2238/ s1.

Author Contributions: Conceptualization, P.U.-M., R.L.-C., J.G.R., and R.D.M.; Data curation, P.U.-M., R.L.-C., and D.P.-G.; Formal analysis, P.U.-M. and R.L.-C.; Funding acquisition, P.U.-M., J.G.R., and R.D.M.; Investigation, P.U.-M. and R.L.-C.; Methodology, P.U.-M., R.L.-C., J.G.R., and R.D.M.; Project administration, P.U.-M., R.L.-C., and R.D.M.; Supervision, P.U.-M. and R.D.M.; Writing—original draft, P.U.-M. and R.L.-C.; Writing-review and editing, P.U.-M., R.L.-C., J.G.R., and R.D.M.

Funding: The present work was partially funded by: FONDECYT No. 3160273 to Paulina Urriola-Muñoz, FONDECYT No. 1150352 to Ricardo D. Moreno, and DI-PUCV 37.0/2017 to Juan G. Reyes.

Conflicts of Interest: The authors declare no conflict of interest. The founding sponsors had no role in the design of the study; in the collection, analyses, or interpretation of data; in the writing of the manuscript, and in the decision to publish the results.

\section{References}

1. Lagos-Cabre, R.; Moreno, R.D. Contribution of environmental pollutants to male infertily: A working model of germ cell apoptosis induced by plasticizers. Biol. Res. 2012, 45, 5-14. [CrossRef] [PubMed]

2. Gore, A.C.; Chappell, V.A.; Fenton, S.E.; Flaws, J.A.; Nadal, A.; Prins, G.S.; Toppari, J.; Zoeller, R.T. EDC-2: The Endocrine Society's Second Scientific Statement on Endocrine-Disrupting Chemicals. Endocr. Rev. 2015, 36, E1-E150. [CrossRef] [PubMed]

3. Bunay, J.; Larriba, E.; Moreno, R.D.; Del Mazo, J. Chronic low-dose exposure to a mixture of environmental endocrine disruptors induces microRNAs/isomiRs deregulation in mouse concomitant with intratesticular estradiol reduction. Sci. Rep. 2017, 7, 3373. [CrossRef] [PubMed]

4. Bunay, J.; Larriba, E.; Patino-Garcia, D.; Cruz-Fernandes, L.; Castaneda-Zegarra, S.; Rodriguez-Fernandez, M.; Del Mazo, J.; Moreno, R.D. Differential Effects of Exposure to Single versus a Mixture of Endocrine-Disrupting Chemicals on Steroidogenesis Pathway in Mouse Testes. Toxicol. Sci. 2017. [CrossRef]

5. Prins, G.S.; Hu, W.Y.; Shi, G.B.; Hu, D.P.; Majumdar, S.; Li, G.; Huang, K.; Nelles, J.L.; Ho, S.M.; Walker, C.L.; et al. Bisphenol A promotes human prostate stem-progenitor cell self-renewal and increases in vivo carcinogenesis in human prostate epithelium. Endocrinology 2014, 155, 805-817. [CrossRef] [PubMed]

6. Sushil, K. Environmental chemicals targeting estrogen signaling pathways. In Endocrine Disruptors in the Environment; Jon Wiley \& Sons: Hoboke, NJ, USA, 2014.

7. U.S. Environmental Protection Agency. Bisphenol A Action Plan. Available online: https://www.epa.gov/ sites/production/files/2015-09/documents/bpa_action_plan.pdf (accessed on 20 October 2017).

8. Wetherill, Y.B.; Akingbemi, B.T.; Kanno, J.; McLachlan, J.A.; Nadal, A.; Sonnenschein, C.; Watson, C.S.; Zoeller, R.T.; Belcher, S.M. In vitro molecular mechanisms of bisphenol A action. Reprod. Toxicol. 2007, 24, 178-198. [CrossRef] [PubMed]

9. Patino-Garcia, D.; Cruz-Fernandes, L.; Bunay, J.; Palomino, J.; Moreno, R.D. Reproductive Alterations in Chronically Exposed Female Mice to Environmentally Relevant Doses of a Mixture of Phthalates and Alkylphenols. Endocrinology 2018, 159, 1050-1061. [CrossRef] [PubMed]

10. Nagao, T.; Wada, K.; Marumo, H.; Yoshimura, S.; Ono, H. Reproductive effects of nonylphenol in rats after gavage administration: A two-generation study. Reprod. Toxicol. 2001, 15, 293-315. [CrossRef]

11. McClusky, L.M.; de Jager, C.; Bornman, M.S. Stage-related increase in the proportion of apoptotic germ cells and altered frequencies of stages in the spermatogenic cycle following gestational, lactational, and direct exposure of male rats to p-nonylphenol. Toxicol. Sci. 2007, 95, 249-256. [CrossRef] [PubMed]

12. Hossaini, A.; Dalgaard, M.; Vinggaard, A.M.; Frandsen, H.; Larsen, J.J. In utero reproductive study in rats exposed to nonylphenol. Reprod. Toxicol. 2001, 15, 537-543. [CrossRef]

13. Soto, A.M.; Maffini, M.V.; Sonnenschein, C. Neoplasia as development gone awry: The role of endocrine disruptors. Int. J. Androl. 2008, 31, 288-293. [CrossRef] [PubMed]

14. Fenton, S.E.; Reed, C.; Newbold, R.R. Perinatal environmental exposures affect mammary development, function, and cancer risk in adulthood. Annu. Rev. Pharmacol. Toxicol. 2012, 52, 455-479. [CrossRef] [PubMed]

15. Tarapore, P.; Ying, J.; Ouyang, B.; Burke, B.; Bracken, B.; Ho, S.M. Exposure to bisphenol A correlates with early-onset prostate cancer and promotes centrosome amplification and anchorage-independent growth in vitro. PLoS ONE 2014, 9, e90332. [CrossRef] [PubMed] 
16. Acevedo, R.; Parnell, P.G.; Villanueva, H.; Chapman, L.M.; Gimenez, T.; Gray, S.L.; Baldwin, W.S. The contribution of hepatic steroid metabolism to serum estradiol and estriol concentrations in nonylphenol treated MMTVneu mice and its potential effects on breast cancer incidence and latency. J. Appl. Toxicol. 2005, 25, 339-353. [CrossRef] [PubMed]

17. Ho, S.M.; Tang, W.Y.; Belmonte de Frausto, J.; Prins, G.S. Developmental exposure to estradiol and bisphenol A increases susceptibility to prostate carcinogenesis and epigenetically regulates phosphodiesterase type 4 variant 4. Cancer Res. 2006, 66, 5624-5632. [CrossRef] [PubMed]

18. Kim, Y.S.; Hwang, K.A.; Hyun, S.H.; Nam, K.H.; Lee, C.K.; Choi, K.C. Bisphenol A and nonylphenol have the potential to stimulate the migration of ovarian cancer cells by inducing epithelial-mesenchymal transition via an estrogen receptor dependent pathway. Chem. Res. Toxicol. 2015, 28, 662-671. [CrossRef] [PubMed]

19. Park, M.A.; Choi, K.C. Effects of 4-nonylphenol and bisphenol A on stimulation of cell growth via disruption of the transforming growth factor-beta signaling pathway in ovarian cancer models. Chem. Res. Toxicol. 2014, 27, 119-128. [CrossRef] [PubMed]

20. Hui, L.; Li, H.; Lu, G.; Chen, Z.; Sun, W.; Shi, Y.; Fu, Z.; Huang, B.; Zhu, X.; Lu, W.; et al. Low Dose of Bisphenol A Modulates Ovarian Cancer Gene Expression Profile and Promotes Epithelial to Mesenchymal Transition via Canonical Wnt Pathway. Toxicol. Sci. 2018. [CrossRef] [PubMed]

21. Urriola-Munoz, P.; Lizama, C.; Lagos-Cabre, R.; Reyes, J.G.; Moreno, R.D. Differential expression and localization of ADAM10 and ADAM17 during rat spermatogenesis suggest a role in germ cell differentiation. Biol. Res. 2014, 47, 31. [CrossRef] [PubMed]

22. Urriola-Munoz, P.; Li, X.; Maretzky, T.; Mcllwain, D.R.; Mak, T.W.; Reyes, J.G.; Blobel, C.P.; Moreno, R.D. The xenoestrogens biphenol-A and nonylphenol differentially regulate metalloprotease-mediated shedding of EGFR ligands. J. Cell. Physiol. 2018, 233, 2247-2256. [CrossRef] [PubMed]

23. Urriola-Munoz, P.; Lagos-Cabre, R.; Moreno, R.D. A mechanism of male germ cell apoptosis induced by bisphenol-A and nonylphenol involving ADAM17 and p38 MAPK activation. PLoS ONE 2014, 9, e113793. [CrossRef] [PubMed]

24. Moreno, R.D.; Urriola-Munoz, P.; Lagos-Cabre, R. The emerging role of matrix metalloproteases of the ADAM family in male germ cell apoptosis. Spermatogenesis 2011, 1, 195-208. [CrossRef] [PubMed]

25. Huang, W.; Quan, C.; Duan, P.; Tang, S.; Chen, W.; Yang, K. Nonylphenol induced apoptosis and autophagy involving the Akt/mTOR pathway in prepubertal Sprague-Dawley male rats in vivo and in vitro. Toxicology 2016, 373, 41-53. [CrossRef] [PubMed]

26. Zunke, F.; Rose-John, S. The shedding protease ADAM17: Physiology and pathophysiology. Biochim. Biophys. Acta 2017, 1864, 2059-2070. [CrossRef] [PubMed]

27. Pruessmeyer, J.; Ludwig, A. The good, the bad and the ugly substrates for ADAM10 and ADAM17 in brain pathology, inflammation and cancer. Semin. Cell Dev. Biol. 2009, 20, 164-174. [CrossRef] [PubMed]

28. Kudo, C.; Wada, K.; Masuda, T.; Yonemura, T.; Shibuya, A.; Fujimoto, Y.; Nakajima, A.; Niwa, H.; Kamisaki, Y. Nonylphenol induces the death of neural stem cells due to activation of the caspase cascade and regulation of the cell cycle. J. Neurochem. 2004, 88, 1416-1423. [CrossRef] [PubMed]

29. Yao, G.; Yang, L.; Hu, Y.; Liang, J.; Liang, J.; Hou, Y. Nonylphenol-induced thymocyte apoptosis involved caspase-3 activation and mitochondrial depolarization. Mol. Immunol. 2006, 43, 915-926. [CrossRef] [PubMed]

30. Kusunoki, T.; Shimoke, K.; Komatsubara, S.; Kishi, S.; Ikeuchi, T. p-Nonylphenol induces endoplasmic reticulum stress-mediated apoptosis in neuronally differentiated PC12 cells. Neurosci. Lett. 2008, 431, 256-261. [CrossRef] [PubMed]

31. Wang, W.; Wang, J.; Wang, Q.; Wu, W.; Huan, F.; Xiao, H. Bisphenol A modulates calcium currents and intracellular calcium concentration in rat dorsal root ganglion neurons. J. Membr. Biol. 2013, 246, 391-397. [CrossRef] [PubMed]

32. Wang, J.L.; Liu, C.S.; Lin, K.L.; Chou, C.T.; Hsieh, C.H.; Chang, C.H.; Chen, W.C.; Liu, S.I.; Hsu, S.S.; Chang, H.T.; et al. Nonylphenol-induced Ca2+ elevation and Ca2+-independent cell death in human osteosarcoma cells. Toxicol. Lett. 2005, 160, 76-83. [CrossRef] [PubMed]

33. Khan, S.Z.; Kirk, C.J.; Michelangeli, F. Alkylphenol endocrine disrupters inhibit IP3-sensitive Ca2+ channels. Biochem. Biophys. Res. Commun. 2003, 310, 261-266. [CrossRef] [PubMed]

34. Gong, Y.; Wu, J.; Huang, Y.; Shen, S.; Han, X. Nonylphenol induces apoptosis in rat testicular Sertoli cells via endoplasmic reticulum stress. Toxicol. Lett. 2009, 186, 84-95. [CrossRef] [PubMed] 
35. Goncalves, R.; Zanatta, A.P.; Cavalari, F.C.; do Nascimento, M.A.W.; Delalande-Lecapitaine, C.; Bouraima-Lelong, H.; Silva, F. Acute effect of bisphenol A: Signaling pathways on calcium influx in immature rat testes. Reprod. Toxicol. 2018, 77, 94-102. [CrossRef] [PubMed]

36. Le Gall, S.M.; Bobe, P.; Reiss, K.; Horiuchi, K.; Niu, X.D.; Lundell, D.; Gibb, D.R.; Conrad, D.; Saftig, P.; Blobel, C.P. ADAMs 10 and 17 represent differentially regulated components of a general shedding machinery for membrane proteins such as transforming growth factor alpha, L-selectin, and tumor necrosis factor alpha. Mol. Biol. Cell 2009, 20, 1785-1794. [CrossRef] [PubMed]

37. Carmona-Gutierrez, D.; Bauer, M.A.; Zimmermann, A.; Aguilera, A.; Austriaco, N.; Ayscough, K.; Balzan, R.; Bar-Nun, S.; Barrientos, A.; Belenky, P.; et al. Guidelines and recommendations on yeast cell death nomenclature. Microb. Cell 2018, 5, 4-31. [CrossRef] [PubMed]

38. Ramirez, M.L.G.; Salvesen, G.S. A primer on caspase mechanisms. Semin. Cell Dev. Biol. 2018, 10. [CrossRef] [PubMed]

39. Rheaume, E.; Cohen, L.Y.; Uhlmann, F.; Lazure, C.; Alam, A.; Hurwitz, J.; Sekaly, R.P.; Denis, F. The large subunit of replication factor $C$ is a substrate for caspase-3 in vitro and is cleaved by a caspase-3-like protease during Fas-mediated apoptosis. EMBO J. 1997, 16, 6346-6354. [CrossRef] [PubMed]

40. ECACC and E.c.o.A.C. Ovarian Cancer Cell Line A2780 (ECACC Catalogue no. 93112519). Available online: https:/ / www.phe-culturecollections.org.uk/media/113526/a112780-cell-line-profile.pdf (accessed on 23 March 2018).

41. McCudden, C.R.; Hains, M.D.; Kimple, R.J.; Siderovski, D.P.; Willard, F.S. G-protein signaling: Back to the future. Cell. Mol. Life Sci. 2005, 62, 551-577. [CrossRef] [PubMed]

42. Rozengurt, E. Mitogenic signaling pathways induced by G protein-coupled receptors. J. Cell. Physiol. 2007, 213, 589-602. [CrossRef] [PubMed]

43. Liu, S.; Premont, R.T.; Rockey, D.C. G-protein-coupled receptor kinase interactor-1 (GIT1) is a new endothelial nitric-oxide synthase (eNOS) interactor with functional effects on vascular homeostasis. J. Biol. Chem. 2012, 287, 12309-12320. [CrossRef] [PubMed]

44. Nishino, Y.; Miura, T.; Miki, T.; Sakamoto, J.; Nakamura, Y.; Ikeda, Y.; Kobayashi, H.; Shimamoto, K. Ischemic preconditioning activates AMPK in a PKC-dependent manner and induces GLUT4 up-regulation in the late phase of cardioprotection. Cardiovasc. Res 2004, 61, 610-619. [CrossRef] [PubMed]

45. Chen, Z.P.; Mitchelhill, K.I.; Michell, B.J.; Stapleton, D.; Rodriguez-Crespo, I.; Witters, L.A.; Power, D.A.; Ortiz de Montellano, P.R.; Kemp, B.E. AMP-activated protein kinase phosphorylation of endothelial NO synthase. FEBS Lett. 1999, 443, 285-289. [CrossRef]

46. Al-Jarallah, A.; Chen, X.; Gonzalez, L.; Trigatti, B.L. High density lipoprotein stimulated migration of macrophages depends on the scavenger receptor class B, type I, PDZK1 and Akt1 and is blocked by sphingosine 1 phosphate receptor antagonists. PLoS ONE 2014, 9, e106487. [CrossRef] [PubMed]

47. Kimura, T.; Tomura, H.; Mogi, C.; Kuwabara, A.; Damirin, A.; Ishizuka, T.; Sekiguchi, A.; Ishiwara, M.; Im, D.S.; Sato, K.; et al. Role of scavenger receptor class B type I and sphingosine 1-phosphate receptors in high density lipoprotein-induced inhibition of adhesion molecule expression in endothelial cells. J. Biol. Chem. 2006, 281, 37457-37467. [CrossRef] [PubMed]

48. De Miguel, M.P.; Cheng, L.; Holland, E.C.; Federspiel, M.J.; Donovan, P.J. Dissection of the c-Kit signaling pathway in mouse primordial germ cells by retroviral-mediated gene transfer. Proc. Natl. Acad. Sci. USA 2002, 99, 10458-10463. [CrossRef] [PubMed]

49. Brizzi, M.F.; Dentelli, P.; Rosso, A.; Yarden, Y.; Pegoraro, L. STAT protein recruitment and activation in c-Kit deletion mutants. J. Biol. Chem. 1999, 274, 16965-16972. [CrossRef] [PubMed]

50. Ryan, J.J.; Huang, H.; McReynolds, L.J.; Shelburne, C.; Hu-Li, J.; Huff, T.F.; Paul, W.E. Stem cell factor activates STAT-5 DNA binding in IL-3-derived bone marrow mast cells. Exp. Hematol. 1997, 25, 357-362. [PubMed]

51. Matsui, J.; Wakabayashi, T.; Asada, M.; Yoshimatsu, K.; Okada, M. Stem cell factor/c-kit signaling promotes the survival, migration, and capillary tube formation of human umbilical vein endothelial cells. J. Biol. Chem. 2004, 279, 18600-18607. [CrossRef] [PubMed]

52. Yuan, T.L.; Cantley, L.C. PI3K pathway alterations in cancer: Variations on a theme. Oncogene 2008, 27, 5497-5510. [CrossRef] [PubMed]

53. Du, K.; Montminy, M. CREB is a regulatory target for the protein kinase Akt/PKB. J. Biol. Chem. 1998, 273, 32377-32379. [CrossRef] [PubMed] 
54. Sancak, Y.; Thoreen, C.C.; Peterson, T.R.; Lindquist, R.A.; Kang, S.A.; Spooner, E.; Carr, S.A.; Sabatini, D.M. PRAS40 is an insulin-regulated inhibitor of the mTORC1 protein kinase. Mol. Cell. 2007, 25, 903-915. [CrossRef] [PubMed]

55. Wang, L.; Harris, T.E.; Roth, R.A.; Lawrence, J.C., Jr. PRAS40 regulates mTORC1 kinase activity by functioning as a direct inhibitor of substrate binding. J. Biol. Chem. 2007, 282, 20036-20044. [CrossRef] [PubMed]

56. Kim, A.H.; Sasaki, T.; Chao, M.V. JNK-interacting protein 1 promotes Akt1 activation. J. Biol. Chem. 2003, 278, 29830-29836. [CrossRef] [PubMed]

57. Krystal, G.W.; DeBerry, C.S.; Linnekin, D.; Litz, J. Lck associates with and is activated by Kit in a small cell lung cancer cell line: Inhibition of SCF-mediated growth by the Src family kinase inhibitor PP1. Cancer Res. 1998, 58, 4660-4666. [PubMed]

58. New, D.C.; Wong, Y.H. Molecular mechanisms mediating the G protein-coupled receptor regulation of cell cycle progression. J. Mol. Signal. 2007, 2, 2. [CrossRef] [PubMed]

59. Silva, C.M. Role of STATs as downstream signal transducers in Src family kinase-mediated tumorigenesis. Oncogene 2004, 23, 8017-8023. [CrossRef] [PubMed]

60. Tichy, A.; Zaskodova, D.; Rezacova, M.; Vavrova, J.; Vokurkova, D.; Pejchal, J.; Vilasova, Z.; Cerman, J.; Osterreicher, J. Gamma-radiation-induced ATM-dependent signalling in human T-lymphocyte leukemic cells, MOLT-4. Acta Biochim. Pol. 2007, 54, 281-287. [PubMed]

61. Dorion, S.; Landry, J. Activation of the mitogen-activated protein kinase pathways by heat shock. Cell Stress Chaperones 2002, 7, 200-206. [CrossRef]

62. Venkatakrishnan, C.D.; Dunsmore, K.; Wong, H.; Roy, S.; Sen, C.K.; Wani, A.; Zweier, J.L.; Ilangovan, G. HSP27 regulates p53 transcriptional activity in doxorubicin-treated fibroblasts and cardiac H9c2 cells: P21 upregulation and G2/M phase cell cycle arrest. Am. J. Physiol. Heart Circ. Physiol. 2008, 294, H1736-H1744. [CrossRef] [PubMed]

63. Sanchez-Prieto, R.; Rojas, J.M.; Taya, Y.; Gutkind, J.S. A role for the p38 mitogen-acitvated protein kinase pathway in the transcriptional activation of p53 on genotoxic stress by chemotherapeutic agents. Cancer Res. 2000, 60, 2464-2472. [PubMed]

64. In, S.J.; Kim, S.H.; Go, R.E.; Hwang, K.A.; Choi, K.C. Benzophenone-1 and nonylphenol stimulated MCF-7 breast cancer growth by regulating cell cycle and metastasis-related genes via an estrogen receptor alpha-dependent pathway. J. Toxicol. Environ. Health Part A 2015, 78, 492-505. [CrossRef] [PubMed]

65. Kang, N.H.; Hwang, K.A.; Kim, T.H.; Hyun, S.H.; Jeung, E.B.; Choi, K.C. Induced growth of BG-1 ovarian cancer cells by 17 beta-estradiol or various endocrine disrupting chemicals was reversed by resveratrol via downregulation of cell cycle progression. Mol. Med. Rep. 2012, 6, 151-156. [CrossRef] [PubMed]

66. Zhang, Y.; Wei, F.; Zhang, J.; Hao, L.; Jiang, J.; Dang, L.; Mei, D.; Fan, S.; Yu, Y.; Jiang, L. Bisphenol A and estrogen induce proliferation of human thyroid tumor cells via an estrogen-receptor-dependent pathway. Arch. Biochem. Biophys. 2017, 633, 29-39. [CrossRef] [PubMed]

67. Li, D.; Zhou, Z.; Qing, D.; He, Y.; Wu, T.; Miao, M.; Wang, J.; Weng, X.; Ferber, J.R.; Herrinton, L.J.; et al. Occupational exposure to bisphenol-A (BPA) and the risk of self-reported male sexual dysfunction. Hum. Reprod. 2010, 25, 519-527. [CrossRef] [PubMed]

68. Kim, S.K.; Kim, B.K.; Shim, J.H.; Gil, J.E.; Yoon, Y.D.; Kim, J.H. Nonylphenol and octylphenol-induced apoptosis in human embryonic stem cells is related to Fas-Fas ligand pathway. Toxicol. Sci. 2006, 94, 310-321. [CrossRef] [PubMed]

69. Sauer, S.J.; Tarpley, M.; Shah, I.; Save, A.V.; Lyerly, H.K.; Patierno, S.R.; Williams, K.P.; Devi, G.R. Bisphenol A activates EGFR and ERK promoting proliferation, tumor spheroid formation and resistance to EGFR pathway inhibition in estrogen receptor-negative inflammatory breast cancer cells. Carcinogenesis 2017, 38, 252-260. [CrossRef] [PubMed]

70. Matthews, A.L.; Noy, P.J.; Reyat, J.S.; Tomlinson, M.G. Regulation of A disintegrin and metalloproteinase (ADAM) family sheddases ADAM10 and ADAM17: The emerging role of tetraspanins and rhomboids. Platelets 2017, 28, 333-341. [CrossRef] [PubMed]

71. Bilancio, A.; Bontempo, P.; Di Donato, M.; Conte, M.; Giovannelli, P.; Altucci, L.; Migliaccio, A.; Castoria, G. Bisphenol A induces cell cycle arrest in primary and prostate cancer cells through EGFR/ERK/p53 signaling pathway activation. Oncotarget 2017, 8, 115620-115631. [CrossRef] [PubMed] 
72. Zhang, Q.; Steinle, J.J. IGFBP-3 inhibits TNF-alpha production and TNFR-2 signaling to protect against retinal endothelial cell apoptosis. Microvasc. Res. 2014, 95, 76-81. [CrossRef] [PubMed]

73. Singh, K.; Piprode, V.; Mhaske, S.T.; Barhanpurkar-Naik, A.; Wani, M.R. IL-3 Differentially Regulates Membrane and Soluble RANKL in Osteoblasts through Metalloproteases and the JAK2/STAT5 Pathway and Improves the RANKL/OPG Ratio in Adult Mice. J. Immunol. 2018, 200, 595-606. [CrossRef] [PubMed]

74. Ma, X.; Xu, D.; Ai, Y.; Zhao, S.; Zhang, L.; Ming, G.; Liu, Z. Angiotensin-(1-7)/Mas Signaling Inhibits Lipopolysaccharide-Induced ADAM17 Shedding Activity and Apoptosis in Alveolar Epithelial Cells. Pharmacology 2016, 97, 63-71. [CrossRef] [PubMed]

75. Michaela, P.; Maria, K.; Silvia, H.; L'Ubica, L. Bisphenol A differently inhibits CaV3.1, Ca V3.2 and Ca V3.3 calcium channels. Naunyn Schmiedebergs Arch. Pharmacol. 2014, 387, 153-163. [CrossRef] [PubMed]

76. Gao, Q.; Liu, S.; Guo, F.; Liu, S.; Yu, X.; Hu, H.; Sun, X.; Hao, L.; Zhu, T. Nonylphenol affects myocardial contractility and L-type $\mathrm{Ca}(2+)$ channel currents in a non-monotonic manner via $\mathrm{G}$ protein-coupled receptor 30. Toxicology 2015, 334, 122-129. [CrossRef] [PubMed]

77. Zhou, H.M.; Weskamp, G.; Chesneau, V.; Sahin, U.; Vortkamp, A.; Horiuchi, K.; Chiusaroli, R.; Hahn, R.; Wilkes, D.; Fisher, P.; et al. Essential role for ADAM19 in cardiovascular morphogenesis. Mol. Cell. Biol 2004, 24, 96-104. [CrossRef] [PubMed]

78. Grynkiewicz, G.; Poenie, M.; Tsien, R.Y. A new generation of Ca2+ indicators with greatly improved fluorescence properties. J. Biol. Chem. 1985, 260, 3440-3450. [PubMed]

79. Sokal, R.R. Biometry: The Principles and Practice of Statistic in Biological Research; W. H. Freeman: New York, NY, USA, 1995; p. 887.

(C) 2018 by the authors. Licensee MDPI, Basel, Switzerland. This article is an open access article distributed under the terms and conditions of the Creative Commons Attribution (CC BY) license (http:/ / creativecommons.org/licenses/by/4.0/). 